\title{
Testicular Sertoli cells exert both protective and destructive effects on syngeneic islet grafts in non-obese diabetic mice
}

\author{
G.S. Korbutt ${ }^{1}$, W.L.Suarez-Pinzon ${ }^{2}$, R.F.Power ${ }^{3}$, R. V. Rajotte ${ }^{1}$, A. Rabinovitch ${ }^{2}$ \\ ${ }^{1}$ Department of Surgery, University of Alberta, Edmonton, Alberta, Canada \\ ${ }^{2}$ Department of Medicine, University of Alberta, Edmonton, Alberta, Canada \\ ${ }^{3}$ Department of Laboratory Medicine and Pathology, University of Alberta, Edmonton, Alberta, Canada
}

\section{Abstract}

Aims/hypothesis. Testicular Sertoli cells protect allogeneic islet grafts from rejection after transplantation into animals with chemically induced diabetes. The aims of this study were to determine whether Sertoli cells can protect syngeneic islets from autoimmune destruction after transplantation into non-obese diabetic (NOD) mice and, if so, whether protection is due to Sertoli cell expression of Fas ligand (FasL), believed to be the mechanism that protects against allograft rejection.

Methods. We compared the survival of syngeneic islets transplanted under the renal capsule of nonobese diabetic mice, alone and together with purified Sertoli cells prepared from testes of newborn nonobese diabetic mice. Additionally, we examined the composition of the islet and Sertoli cell co-transplants by immunohistochemistry to determine whether islet graft survival correlated with Sertoli cell expression of Fas ligand.
Results. Sertoli cell doses of 1,2 and $4 \times 10^{6}$ cells produced a dose-dependent prolongation of median islet graft survival from 11 days (islets alone) to 32 days (islets $+4 \times 10^{6}$ Sertoli cells); addition of $8 \times 10^{6} \mathrm{Ser}-$ toli cells to the islet grafts decreased, however, median survival to 8 days. Immunohistochemical analysis of the islet and Sertoli cell co-transplants showed a correlation between Fas ligand expression by Sertoli cells and graft infiltration by neutrophilic leucocytes, leading to islet beta-cell destruction and diabetes recurrence.

Conclusion/interpretation. Sertoli cells exert opposing effects on survival of syngeneic islet grafts in nonobese diabetic mice: Fas ligand-dependent neutrophil infiltration and graft destruction, and Fas ligand-independent protection of the graft from autoimmune destruction. [Diabetologia (2000) 43: 474-480]

Keywords Type I diabetes, NOD mice, islet transplantation, beta cells, Sertoli cells, Fas ligand, neutrophils.
Certain tissues such as brain, anterior chamber of the eye and testis have been termed immunologically privileged because immune responses to "non-self" antigens are reduced at these sites [1]. For example,

Received: 13 December 1999 and in revised form: 20 January 2000

Corresponding author: A. Rabinovitch, M.D., 430 Heritage Medical Research Centre, University of Alberta, Edmonton, Alberta, Canada T6G 2S2

Abbreviations: NOD, Non-obese diabetic; SC, Sertoli cells; FasL, Fas ligand; HBSS, Hank's balanced salt solution; FSHr, follicle-stimulating hormone receptor; ABP, androgen binding protein. allogeneic [2] and xenogeneic [3] pancreatic islets survive transplantation in the testis with little immunosuppression. Recent studies have suggested that expression of Fas ligand (FasL or CD95L) by cells in immunologically privileged tissues is the mechanism by which these tissues kill Fas receptor (Fas or CD95)-bearing alloreactive T-cells that would otherwise destroy the allograft [4-6]. Evidence that FasL expression by testicular tissue is the mechanism conferring immune privilege to the testis comes from studies in which testis allografts from normal mice were accepted, whereas testis allografts from mice expressing non-functional FasL were rejected [7]. Similarly, mouse islet allografts survived longer after co- 
transplantation with FasL-expressing testicular tissue than after co-transplantation with testicular tissue expressing non-functional FasL [8]. In addition, cotransplantation of islets and myoblasts genetically engineered to express FasL prolonged islet allograft survival in streptozotocin-diabetic mice [9]. In more recent studies FasL expression by mouse beta cells, achieved either transgenically $[10,11]$ or by gene transfection [11,12], failed, however, to protect islet allografts (or even isografts) from rejection; rather FasL was proinflammatory and induced an intense infiltration of neutrophils into the grafts.

Sertoli cells have been identified as the component in testicular tissue that confers immune privilege to allografts [13], including islet allografts [14-17]. The latter studies have shown that Sertoli cells protect allogeneic islet grafts from rejection after transplantation into chemically diabetic rats and mice; it is, however, not known if Sertoli cells can prevent autoimmune destruction of islet beta cells. Therefore, the aims of the present study were to determine whether Sertoli cells can protect syngeneic islets from autoimmune destruction after transplantation into nonobese diabetic (NOD) mice and, if so, whether protection is due to FasL expression by the Sertoli cells.

\section{Materials and methods}

Animals. Male and female NOD mice (Taconic, Germantown, N. Y., USA), aged 4 weeks, were used as islet donors and male NOD mice, aged 9-12 days, were used as testicular Sertoli cell donors. Diabetic NOD mice (males and females, aged 17-22 weeks) were used as recipients of islet and Sertoli cell grafts. Diabetic mice (diabetes duration 3-6 weeks) were treated by daily subcutaneous injections of ultralente beef and pork insulin (1.0 U/100 g body weight) until the day before transplantation. All mice were cared for according to the guidelines of the Canadian Council on Animal Care; killing was by pentobarbital anaesthetic overdose.

Islet and Sertoli cell preparations. Islets were isolated from NOD mice by collagenase digestion of the pancreas and Ficoll density gradient centrifugation and then hand picked before transplantation [18]. Testes from NOD mice were collected in Hank's balanced salt solution (HBSS), chopped into 1-mm pieces with scissors and digested for 10 min at $37^{\circ} \mathrm{C}$ with collagenase $(2.5 \mathrm{mg} / \mathrm{ml}$; Sigma Type V, St. Louis, Mo., USA) in HBSS. The digest was washed three times with $\mathrm{Ca}^{2+} / \mathrm{Mg}^{2+}-$ free HBSS containing $1 \mathrm{mmol} / \mathrm{l}$ EDTA and $0.5 \%$ bovine serum albumin (HBSS/EDTA, Sigma), digested for $10 \mathrm{~min}$ at $37^{\circ} \mathrm{C}$ with trypsin $(25 \mu \mathrm{g} / \mathrm{ml}$; Boehringer Mannheim, Laval, Quebec, Canada) and DNase $(4 \mu \mathrm{g} / \mathrm{ml}$, Boehringer Mannheim) in HBSS/EDTA and washed four times in HBSS. The final cell pellet was resuspended in M199 medium (Life Technologies, Burlington, Ontario, Canada) supplemented with $10 \%$ heat-inactivated horse serum, passed through a $500-\mu \mathrm{m}$ mesh, placed in $150 \times 15 \mathrm{~mm}$ non-tissue, culture-coated Petri dishes and incubated for 3 days at $37^{\circ} \mathrm{C}\left(5 \% \mathrm{CO}_{2}\right)$ before transplantation to allow the testicular cells to reaggregate [17]. Furthermore, in the study, we found that there was a preferential survival of Sertoli cells during the 3-day culture peri- od. Sertoli cell purity was evaluated by immunohistochemical staining for markers that are specific to Sertoli cells in testicular-cell preparations: follicle-stimulating hormone receptor (FSHr) [19] and androgen binding protein (ABP) [20]. Thus, fresh preparations of testicular cells from 9 to 12 day-old NOD mice were composed of $52 \pm 4 \% \mathrm{FSHr}^{+}$cells and $60 \pm 6 \% \mathrm{ABP}^{+}$cells, and the Sertoli cell purity increased to $83 \pm 4 \% \mathrm{FSHr}^{+}$cells and $94 \pm 3 \% \mathrm{ABP}^{+}$cells after 3 days of culture (means \pm SEM, $n=4$ preparations). Each preparation of Sertoli cells was obtained from a pool of 20 testes (10 NOD mice) and, after culture, approximately $1 \times 10^{6}$ Sertoli cells were recovered from each testis. Before transplantation, an aliquot $(1 \mathrm{ml})$ of a suspension of the 3-day cultured Sertoli cell aggregates (35 ml for cells prepared from 20 testes) was dissociated into single cells by incubation at room temperature for 10 min in enzyme-free Hank's-based cell dissociation buffer (Life Technologies), followed by syringing through a 22-gauge needle ten times, to obtain a cell count and calculate the number of Sertoli cells in the cell aggregates transplanted.

Transplantations. Each diabetic NOD mouse was anaesthetised with Halothane and transplanted under the left renal capsule with either 500 freshly isolated islets (pooled from approximately three donor NOD mice) or islets together with 1, 2, 4, or $8 \times 10^{6}$ Sertoli cells cultured for 3 days (pooled from one to eight donor NOD mice). Before transplantation, the Sertoli cell aggregates were washed twice in RPMI 1640 medium (Life Technologies) supplemented with 1\% NOD mouse serum. Transplantations of islets and Sertoli cells were carried out as follows. First, 250 islets, then $0.5,1,2$ or $4 \times 10^{6}$ Sertoli cells were aspirated into polyethylene tubing (PE-50) and the islets and cells were pelleted by centrifugation for $2 \mathrm{~min}$, then implanted under the left renal capsule on the lateral aspect of the kidney. This procedure was repeated and another 250 islets and $0.5,1,2$ or $4 \times 10^{6}$ Sertoli cells were implanted under the left renal capsule on the medial (hilar) aspect of the same kidney. Transplantation was considered successful if the non-fasting blood glucose returned to normal $(<7.0 \mathrm{mmol} / \mathrm{l})$ within $12 \mathrm{~h}$ after transplantation. Tail vein blood glucose was monitored daily after transplantation, by using an Accu-Chek IIm glucose monitor (Boehringer Mannheim). Graft rejection was diagnosed by return of hyperglycaemia (blood glucose $>11.1 \mathrm{mmol} / \mathrm{l}$ ) accompanied by glucosuria and ketonuria on 2 consecutive days.

Experimental design. In the first study, we examined the dosedependent effects of Sertoli cells $\left(1,2,4\right.$ and $\left.8 \times 10^{6}\right)$ on survival of syngeneic islet grafts in NOD mice. The mice with the transplants were monitored daily by blood glucose measurements and the day of diabetes recurrence after transplantation defined the duration of graft survival. The mice were killed at the time of diabetes recurrence or at 60 days after transplantation if still normoglycaemic and graft survival was compared in the recipients of islet-only and islet plus Sertoli cell composite grafts. Also, composite grafts that survived to 60 days were examined histologically and the cellular composition of the grafts was studied by immunohistochemistry. In the second study, we examined the cell composition of the composite grafts of islets plus Sertoli cells by immunohistochemistry and leucocyte differential staining $6 \mathrm{~h}$ after transplantation (day 0 ) and at 7-20 days after transplantation, in mice in which diabetes had recurred (within the previous $24 \mathrm{~h}$ ) and in mice which were still normoglycaemic.

Histological studies. Grafts were fixed in $10 \%$ buffered formalin, embedded in paraffin, sectioned at $4.5 \mu \mathrm{m}$, stained with an anti-insulin antibody (Dako, Carpenteria, Calif., USA) using 
an immunoperoxidase technique and then counterstained with haematoxylin. Coded slides were examined by light microscopy.

Graft cell preparations. Grafts were removed from the renal subcapsular space, placed in RPMI-1640 medium supplemented with $10 \%$ heat-inactivated fetal calf serum (Life Technologies) and kept on ice, then transferred into Eppendorf tubes containing $500 \mu \mathrm{l} \mathrm{Ca} \mathrm{Ca}^{2+} / \mathrm{Mg}^{2+}$-free PBS with $0.2 \mathrm{mg} / \mathrm{ml}$ EDTA (cell dissociation buffer) (Life Technologies). Grafts were processed separately from each mouse. While on ice, the grafts were cut into small pieces with fine scissors and disrupted mechanically by syringe injection though progressively narrower gauge needles. The resulting tissue fragments were then dissociated into single cells by incubation in the cell dissociation buffer at $37^{\circ} \mathrm{C}$ for $20 \mathrm{~min}$. A cell count was obtained on an aliquot of total cells isolated from each graft and a total graft cell count was calculated.

Leucocyte staining. Differential leucocyte staining of cells isolated from the grafts was done by the buffered differential Wright-Giemsa cytochemical stain technique (Baxter Scientific, McGaw Park, Ill., USA).

Immunohistochemical studies. Immunohistochemical staining of the graft was done to identify and quantify islet beta cells $\left(\mathrm{R}^{2} 6^{+}\right)$, leucocytes $\left(\mathrm{CD}^{4} 5^{+}\right)$, Sertoli cells $\left(\mathrm{FSHr}^{+}\right)$and FasL-expressing cells $\left(\mathrm{FasL}^{+}\right)$as follows. The cells were fixed in $4 \%$ paraformaldehyde in PBS for 15 min at room temperature and washed twice in PBS by centrifugation at $400 \mathrm{~g}$ for $5 \mathrm{~min}$ at $4{ }^{\circ} \mathrm{C}$. The fixed cells $\left(20 \times 10^{3}\right.$ in $\left.10 \mu \mathrm{l}\right)$ were placed on glass slides coated with 3-aminopropyltriethoxysilane (Sigma) and the slides were stored at $-86^{\circ} \mathrm{C}$ until processed. Slides were thawed and the cells attached to the slides were treated with $1 \%$ paraformaldehyde in PBS at $4{ }^{\circ} \mathrm{C}$ for $10 \mathrm{~min}$, then washed twice in cold PBS and incubated in $0.3 \% \mathrm{H}_{2} \mathrm{O}_{2}$ in PBS for $10 \mathrm{~min}$. Cells were then incubated for $3 \mathrm{~h}$ at room temperature in PBS containing the following sera to block non-specific binding of secondary antibodies: $10 \%$ normal goat serum (for R2D6 ${ }^{+}$cells, $\mathrm{CD}^{+} 5^{+}$cells and $\mathrm{FasL}^{+}$cells), $30 \%$ normal rabbit serum (for $\mathrm{FSHr}^{+}$cells) and $1 \%$ normal goat serum (for $\mathrm{ABP}^{+}$cells). Next, cells were incubated for $2 \mathrm{~h}$ at $4^{\circ} \mathrm{C}$ in a humidity chamber with the following primary antibodies: a mouse mAb to islet beta cells (R2D6 provided by Dr R. Alejandro, Miami, Fla., USA) [21] or mouse IgM control antibody, $10 \mu \mathrm{g} / \mathrm{ml}$; rat mAbs to different mouse leucocyte subsets: Ly-5/T200 (CD45), L3T4 (CD4), Lyt-2 (CD8), M1/70 (Mac-1) and Ly-5/B220 (B cell) (Cedarlane, Hornby, Ontario, Canada) or rat IgG control antibody, $10 \mu \mathrm{g} / \mathrm{ml}$; and a sheep antibody to FSHr (Biogenesis, Poole, UK) or sheep IgG control antibody, $4 \mu \mathrm{g} / \mathrm{ml}$. Cells were then washed in PBS for $30 \mathrm{~min}$ and incubated for $20 \mathrm{~min}$ at room temperature with their respective secondary antibodies: biotinylated goat anti-mouse IgM (Cedarlane), diluted 1:30 in PBS (for R2D6 ${ }^{+}$ cells); biotinylated goat anti-rat mouse-absorbed IgG (Cedarlane), diluted 1:50 in PBS (for $\mathrm{CD}_{4} 5^{+}, \mathrm{CD}^{+}, \mathrm{CD}^{+}, \mathrm{Mac}^{+}{ }^{+}$ and $\mathrm{B}$ cells); biotinylated rabbit anti-goat $\mathrm{IgG}$, cross-reactive to sheep IgG and mouse-absorbed (Vector Laboratories, Burlingame, Calif., USA), diluted 1:150 in $\mathrm{PBS}$ (for $\mathrm{FSHr}^{+}$cells). Cells were washed in PBS, incubated with streptavidin-alkaline phosphatase conjugate (Zymed Laboratories, South San Francisco, Calif., USA) for $15 \mathrm{~min}$ at room temperature, washed in PBS and incubated with a 1:2 dilution of alkaline phosphatase Fast-blue (Vector) for 3-5 min until staining (blue) for the respective cell-specific antigens (CD45, R2D6 or FSHr) reached a maximum intensity as observed under the microscope. This was followed by sealing the stained slides with Crystal Mount (Biomeda, Foster City, Calif., USA) at $60^{\circ} \mathrm{C}$ for $40 \mathrm{~min}$, then with Permount (Fisher Scientific, Napean, Ontario, Canada).

Sertoli cells expressing FasL $\left(\mathrm{FSHr}^{+} \mathrm{FasL}^{+}\right)$were identified by a two-colour immunohistochemical method as follows. First, the Sertoli cells were stained (blue on the cell surface) using the anti-FSHr antibody as described above. Then, FasL antigen was stained by incubating the cells at $34^{\circ} \mathrm{C}$ for $2 \mathrm{~h}$ with $3 \mu \mathrm{g} / \mathrm{ml}$ of a rabbit anti-mouse FasL (CD95L) antibody (Q-20, Santa Cruz Biotechnology, Calif., USA) or $3 \mu \mathrm{g} / \mathrm{ml}$ of a rabbit IgG control antibody. We have previously validated this antiFasL antibody to detect FasL $^{+}$cells by immunohistochemical staining [22]. After staining with anti-FasL or control antibody, cells were washed in PBS for $30 \mathrm{~min}$ and incubated for $30 \mathrm{~min}$ at room temperature with a secondary antibody, biotinylated goat anti-rabbit IgG (Zymed), diluted 1:1 in PBS. Cells were then washed in PBS for $30 \mathrm{~min}$ and incubated for $15 \mathrm{~min}$ at room temperature in PBS diluted 1:1 with streptavidin-peroxidase conjugate (Histostain-SP kit, Zymed). After brief washing in PBS, cells were incubated with a substrate chromogen, 3-amino, 9-ethylcarbazole for 3 to $5 \mathrm{~min}$ until the staining (red) of FasL was maximum. By this method, $\mathrm{FasL}^{+}$cells were stained red intracellularly and $\mathrm{FasL}^{+} \mathrm{FSHr}^{+}$(Sertoli) cells were stained red intracellularly and blue on the cell surface. Cell preparations were stained in duplicate with each test or control antibody and 3000 cells were scored blindly by each of two independent observers who each scanned 60 different microscopic fields (oil immersion, 100x).

Statistical analysis. Median graft survival times were compared by Welch's unpaired $t$ test. Graft cell composition data are presented as means \pm SEM, and statistical comparisons were made by ANOVA followed by Dunnett's test. A $p$ value less than 0.05 was considered statistically significant.

\section{Results}

Effects of Sertoli cells on islet graft survival. Syngeneic islet transplantation corrected hyperglycaemia in diabetic NOD mice immediately after transplantation. Diabetes recurred, however, (blood glucose $>11.1 \mathrm{mmol} / \mathrm{l}$ ) between day 8 and 14 after transplantation. Co-transplantation of syngeneic Sertoli cells $\left(\mathrm{SC}, 1-4 \times 10^{6}\right)$ with the islets prolonged their survival (Fig.1). Median survival was 11 days for grafts of islets alone, 18 days for islets plus $1 \times 10^{6} \mathrm{SC}, 28$ days for islets plus $2 \times 10^{6} \mathrm{SC}(p<0.01)$ and 32 days for islets plus $4 \times 10^{6} \mathrm{SC}(p<0.001)$. Also, $40 \%$ (8 of 20$)$ of mice that received islets and $4 \times 10^{6} \mathrm{SC}$ remained normoglycaemic for at least 60 days after transplantation whereas none ( 0 of 9 ) of mice that received islet-only grafts remained normoglycaemic by 14 days after transplantation. In contrast to the dose-dependent protective effects of 1,2 and $4 \times 10^{6} \mathrm{SC}$ on islet graft survival, $8 \times 10^{6} \mathrm{SC}$ did not protect islets from autoimmune destruction, and median graft survival was reduced to 8 days (Fig. 1).

Histology of islet and Sertoli cell grafts. Islet and Sertoli cell composite grafts were examined at 60 days after transplantation in NOD mice that remained 


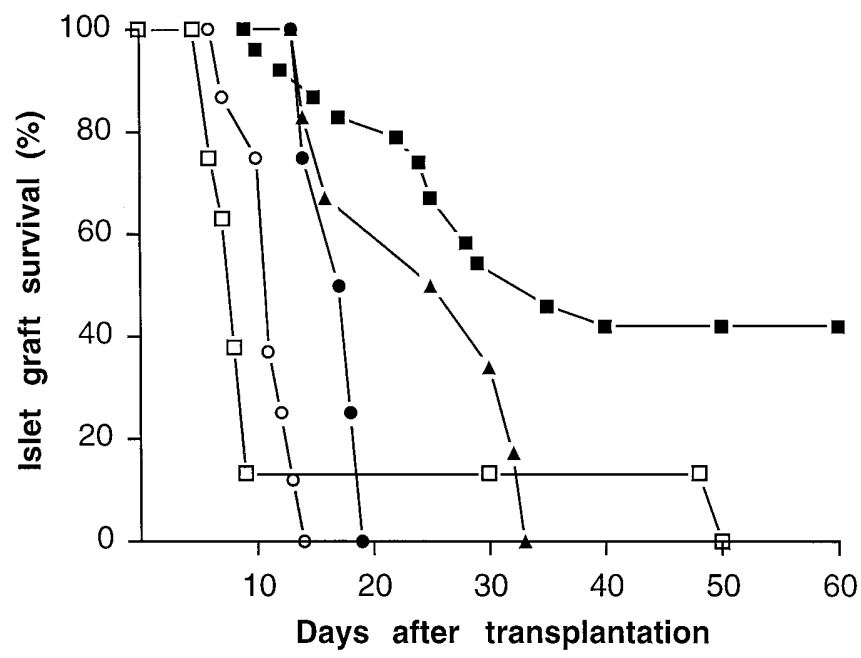

Fig.1. Islet graft survival curves for diabetic NOD mice transplanted with NOD islets alone $(O, n=9)$ and NOD islets together with different doses of NOD Sertoli cells (SC): $1 \times 10^{6}$ $\mathrm{SC}(\boldsymbol{O}, n=4), 2 \times 10^{6} \mathrm{SC}(\boldsymbol{\Delta}, n=6), 4 \times 10^{6} \mathrm{SC}(\boldsymbol{\square}, n=20)$ and $8 \times 10^{6} \mathrm{SC}(\square, n=8)$. Increasing doses from 1 to $4 \times 10^{6}$ $\mathrm{SC}$ produced a dose-dependent prolongation of islet graft survival whereas $8 \times 10^{6} \mathrm{SC}$ reduced median islet graft survival

normoglycaemic after receiving the co-transplants. Beta cells that stained for insulin survived in these composite grafts. Leucocytes still, however, infiltrated the grafts and surrounded the islet cells (Fig.2).

Cell composition of islet and Sertoli cell composite grafts. We compared the cellular composition of composite grafts of islets and Sertoli cells $\left(4 \times 10^{6} \mathrm{SC}\right)$ that failed (diabetes recurred) with those that succeeded in maintaining normoglycaemia (Fig. 3). Islet and SC composite grafts initially consisted of beta cells $\left(0.56 \pm 0.06 \times 10^{6}\right)$ and SC $\left(4.0 \pm 0.2 \times 10^{6}\right)$, with $93 \pm 2 \%$ of the SC expressing FasL. At 10 to 20 days after transplantation, grafts from mice in which diabetes had recurred (within the previous $24 \mathrm{~h}$ ) contained numerous leucocytes $\left(6.1 \pm 0.3 \times 10^{6}\right)$ and statistically significantly decreased numbers of beta cells $\left(0.16 \pm 0.02 \times 10^{6}\right)$ and SC $\left(2.8 \pm 0.1 \times 10^{6}\right)$ compared with the initial numbers of these cells in the grafts. The remaining SC retained, however, their expression of FasL $(95 \pm 6 \%$ compared with $93 \pm 2 \%$ at the time of transplantation). In contrast, grafts from mice that were normoglycaemic at 10 to 20 days after transplantation contained fewer leucocytes $(2.2 \pm 0.3$ $\times 10^{6}$ ) and similar numbers of beta cells and SC to that initially transplanted. The expression FasL by the SC was, however, statistically significantly decreased $(48 \pm 6 \%)$ from the time of transplantation $(93 \pm 2 \%)$. Furthermore, grafts from mice that remained normoglycaemic at 60 days after transplantation contained even fewer leucocytes $\left(1.7 \pm 0.2 \times 10^{6}\right)$, beta cells and SC were not statistically significantly decreased from the numbers initially transplanted and FasL expression by SC was almost completely lost $(6 \pm 2 \%)$ compared with the initial expression of FasL by SC $(93 \pm 2 \%)$.

Leucocyte subsets in islet and Sertoli cell composite grafts. Total leucocytes (CD $45^{+}$cells) were significantly greater in grafts from mice that were transplanted with islets plus either $4 \times 10^{6} \mathrm{SC}$ or $8 \times 10^{6} \mathrm{SC}$, and in which diabetes recurred, than in grafts from mice that were transplanted with islets plus $4 \times 10^{6} \mathrm{SC}$ and remained normoglycaemic (Fig. 4). Grafts infiltrated with the most leucocytes contained significantly greater percentages of $\mathrm{CD}^{+}$and $\mathrm{CD}^{+} \mathrm{T}$-cells and significantly lower percentages of $\mathrm{B}$ cells and macrophages, as determined by immunohistochemical staining. Similarly, percentages of lymphocytes were significantly increased and monocytes were significantly decreased in grafts infiltrated with the most leucocytes, as determined by differential leucocyte staining. Interestingly, neutrophils were significantly increased in grafts from mice that were transplanted with islets plus either $4 \times 10^{6} \mathrm{SC}$ or $8 \times 10^{6} \mathrm{SC}$, and in which diabetes recurred, compared with grafts from mice that were transplanted with islets plus $4 \times 10^{6}$ $\mathrm{SC}$ and remained normoglycaemic (Fig.4).

Correlation of Fas $L^{+}$cells and neutrophils in grafts. Islet and Sertoli cell composite grafts that were rejected had the highest expression of FasL by Sertoli cells (Fig. 3) and the most leucocytic and neutrophilic infiltration (Fig.4) and graft infiltration by neutrophils correlated significantly with numbers of $\mathrm{FasL}^{+}$cells in the grafts (Fig.5).

\section{Discussion}

This study shows that co-transplantation of testicular Sertoli cells with islets prolongs the survival of syngeneic islets transplanted into NOD mice with autoimmune diabetes. We found that $40 \%$ (8 of 20) of diabetic NOD mice were normoglycaemic at 60 days after receiving a composite graft of syngeneic islets and Sertoli cells but none ( 0 of 9 ) of islet-only recipients remained normoglycaemic beyond 14 days. In a previous study, we found that all (5 of 5) streptozocin-diabetic rats were normoglycaemic at 95 days after receiving a composite graft of allogeneic islets and Sertoli cells [17]. Because the immune response to islet transplantation in a recipient with autoimmune diabetes is different and more difficult to suppress than the allograft response in a recipient with nonautoimmune diabetes [23], this could explain, at least in part, why Sertoli cells were not as completely effective in preventing rejection of syngeneic islets in an autoimmune diabetic recipient (present study) as they were in preventing rejection of allogeneic islets in a chemically induced diabetic recipient [17]. 

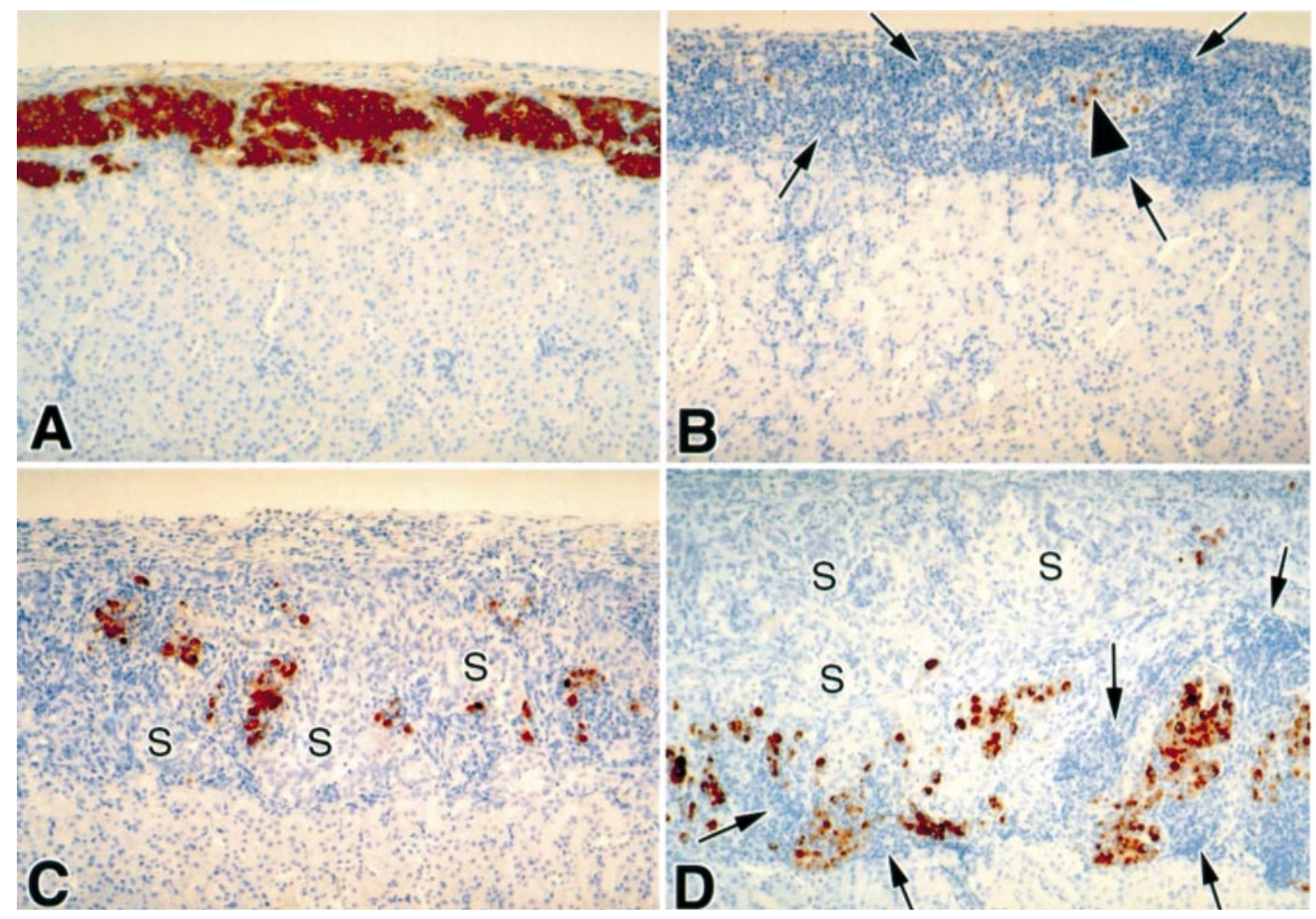

\section{$100 \mu$}

Fig. 2 A-D. Photomicrographs of islet grafts (A and $\mathbf{B})$ and islet plus Sertoli cell composite grafts $(\mathbf{C}$ and $\mathbf{D})$ transplanted under the renal capsule in diabetic NOD mice. At $6 \mathrm{~h}$ after transplantation, abundant insulin-staining beta cells (brown) were detected in islet grafts situated beneath the renal capsule and overlying the kidney (A). At 10 days after transplantation, the islet grafts were heavily infiltrated by leucocytes (arrows), very few beta cells remained (arrowhead) and diabetes recurred (B). In contrast, when islets were co-transplanted with $4 \times 10^{6}$ Sertoli cells, beta cells (brown) and clusters of Sertoli cells (S) were detected in the composite grafts at $6 \mathrm{~h}(\mathbf{C})$ and at 60 days after transplantation $(\mathbf{D})$. Also, beta cells in composite grafts at 60 days were surrounded but not destroyed by infiltrating leucocytes (arrows) and the mice remained normoglycaemic (D)

The dose-dependent effects of adding Sertoli cells to islet grafts were unexpected. Increasing the dose of Sertoli cells from 1 to $4 \times 10^{6}$ cells progressively increased survival of the composite grafts. A further increase to $8 \times 10^{6}$ Sertoli cells resulted, however, in accelerated islet graft rejection and recurrent diabetes. Notably, prevention of graft rejection was associated with loss of FasL expression by the Sertoli cells. The majority of Sertoli cells expressed FasL $(93 \pm 2 \%)$ at the time of transplantation and this gradually disappeared in mice that remained normoglycaemic ( $48 \pm 6 \%$ of Sertoli cells were $\mathrm{FasL}^{+}$at $10-20$ days and only $6 \pm 2 \%$ of Sertoli cells were $\mathrm{FasL}^{+}$at 60 days after transplantation). In contrast, FasL expression by Sertoli cells remained high in mice that became diabetic $\left(95 \pm 6 \%\right.$ of Sertoli cells were $\mathrm{FasL}^{+}$ at 10-20 days after transplantation). Therefore, FasL
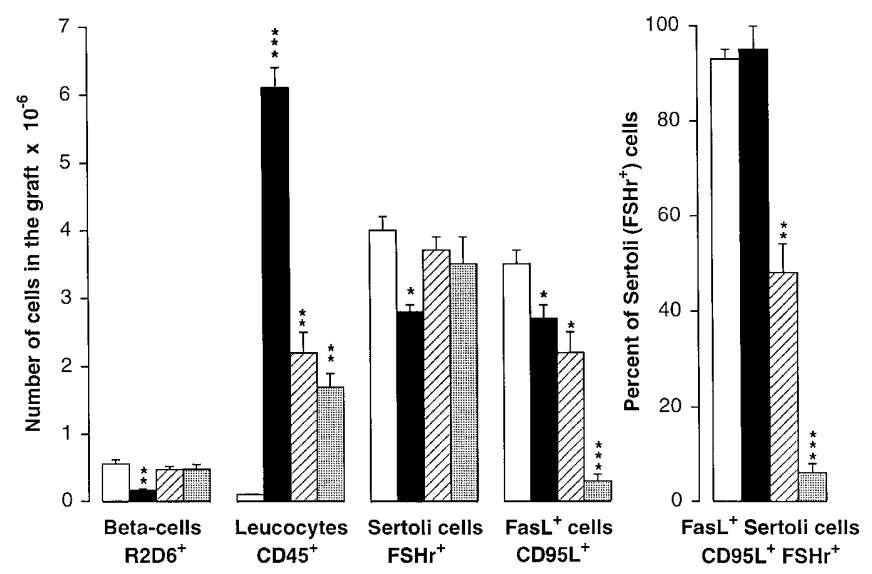

Fig. 3. Immunohistochemical analysis of composite grafts of NOD mouse islets and Sertoli cells $\left(4 \times 10^{6}\right)$ co-transplanted into diabetic NOD mice. The grafts were examined at $6 \mathrm{~h}$ after transplantation $(\square, n=4)$, at 10 to 20 days after transplantation in mice in which diabetes recurred $(\square, n=6)$, at 10 to 20 days in mice which remained normoglycaemic ( $\mathbb{Z}, n=6)$ and at 60 days in mice which remained normoglycaemic $(\square$, $n=8)$. Cell compositions of the grafts were determined by immunohistochemistry using antibodies to the different cell types indicated. Values are means \pm SEM. $* p<0.05$, $* * p<0.01$, $* * * p<0.001$ vs $6 \mathrm{~h}$ after transplantation

expression by Sertoli cells was associated with failure of these cells to protect beta cells from autoimmune destruction. In addition, we found that FasL expression by Sertoli cells in composite grafts correlated statistically significantly with neutrophilic leucocyte infiltration of the graft. This observation is consistent with reports that FasL expression by mouse beta cells, 

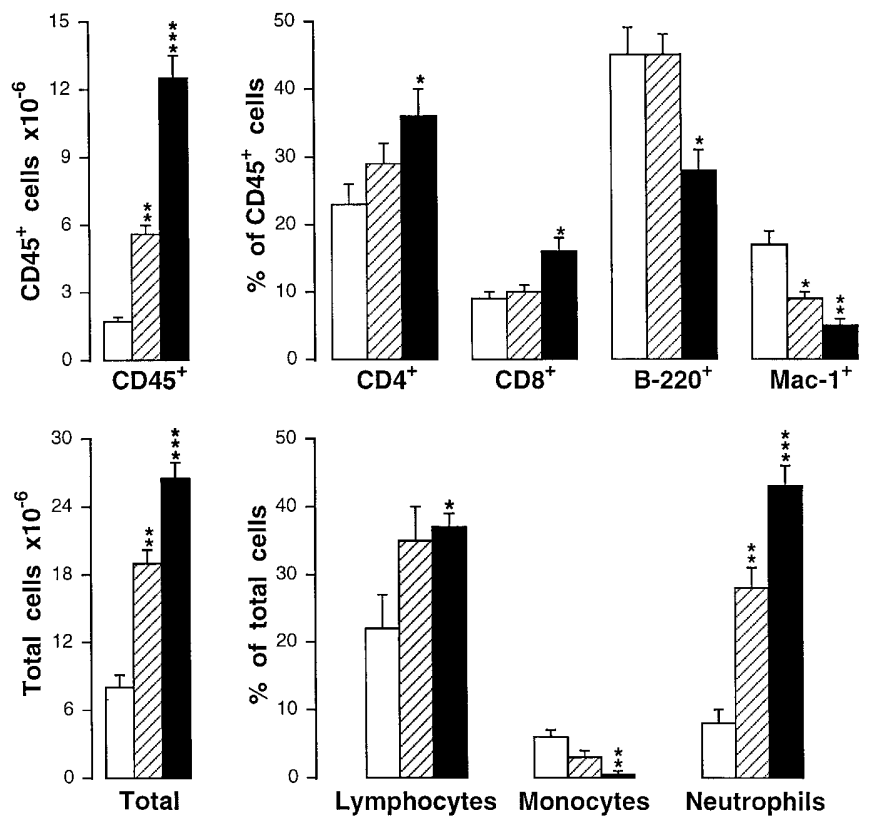

Fig.4. Leucocyte subsets in islet and Sertoli cell composite grafts. The grafts were studied at 7 to 20 days after transplantation in mice transplanted with islets plus $4 \times 10^{6}$ Sertoli cells and remaining normoglycaemic $(\square, n=7)$, mice transplanted with islets plus $4 \times 10^{6}$ Sertoli cells and diabetes recurring (U, $n=9)$ and mice transplanted with islets plus $8 \times 10^{6}$ Sertoli cells and diabetes recurring $(\square, n=6)$. Values are means \pm SEM. $* p<0.05, * * p<0.01, * * * p<0.001$ vs

achieved transgenically $[10,11]$ or by gene transfection $[11,12]$, failed to protect islet allografts (or even isografts) from rejection; rather FasL was proinflammatory and induced an intense infiltration of neutrophils into the islet grafts and graft destruction. The mechanism of FasL-induced neutrophil recruitment has been ascribed to a chemoattractant action of FasL on neutrophils [24-26].

Our finding of an inverse relation between FasL expression by Sertoli cells and prevention of autoimmune destruction of beta cells in islet grafts suggests that FasL is not the mechanism of Sertoli cell-induced protection. Islet grafts were found to survive 60 days after co-transplantation with Sertoli cells that lost FasL expression. These findings seem to conflict with a report that FasL expression by testicular cells delayed the rejection of mouse islet allografts [8]. Islet allografts in the latter study were, however, transplanted into animals with streptozotocin-induced diabetes and not autoimmune diabetes.

How might Sertoli cells protect islet beta cells from autoimmune destruction, if this is not due to FasL expression? Sertoli cells have been reported to secrete proteins that inhibit lymphocyte proliferation [27-31] and interleukin 2 (IL-2) production [30, 31] and these actions would be expected to suppress an autoimmune response. Sertoli cells are responsible for the synthesis and secretion of a variety of differ-

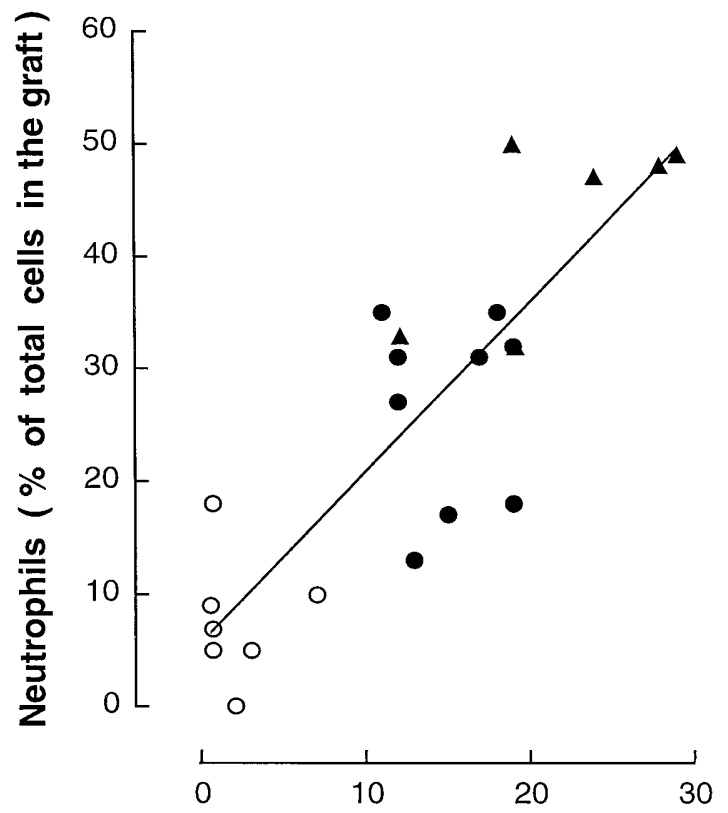

Fas $\mathrm{L}^{+}$cells (\% of total cells in the graft)

Fig. 5. Neutrophils infiltrating islet and Sertoli cell composite grafts correlate with $\mathrm{FasL}^{+}$cells in the grafts. The grafts were studied at 7 to 20 days after transplantation in mice transplanted with islets plus $4 \times 10^{6}$ Sertoli cells and remaining normoglycaemic $(\bigcirc, n=7)$, mice transplanted with islets plus $4 \times 10^{6}$ Sertoli cells and diabetes recurring $(\mathcal{O}, n=9)$ and mice transplanted with islets plus $8 \times 10^{6}$ Sertoli cells and diabetes recurring $(\boldsymbol{\Lambda}, n=6)$. Pearson's correlation coefficient $(r=0.8521)$ is significant $(p<0.0001)$ as determined by paired $t$ test

ent products, including transport and binding proteins, proteases and inhibitors, extracellular matrix components, regulatory proteins, metabolites and growth factors and cytokines - including interleukins 1 and 6 (IL-1 and IL-6), interferon gamma (IFN $\gamma$ ), insulin-like growth factor I (IGF-I), and transforming growth factor beta $(\mathrm{TGF} \beta)[32,33]$. Some of these Sertoli cell products could qualify as mediators of the immunosuppressive effects of Sertoli cells. For example, TGF $\beta$ suppresses many immune responses, including autoimmune diabetes $[34,35]$. In recent studies, we found that IGF-I and TGF $\beta 1$ were highly expressed by Sertoli cells when FasL expression was low on these cells in islet and Sertoli cell co-transplants that maintained normoglycaemia in NOD mice (unpublished data).

Our study shows that testicular Sertoli cells have opposing effects on survival of syngeneic islet grafts in NOD mice: FasL-dependent neutrophil infiltration and graft destruction, and FasL-independent graft protection from autoimmune destruction. The FasLindependent protective effects of Sertoli cells could be mediated by immunosuppressive factors secreted by Sertoli cells, such as IGF-I and TGF $\beta 1$. Strategies to prevent the FasL-dependent effects of Sertoli cells, while preserving or increasing the FasL-independent effects, might be expected to improve the net protec- 
tive effects of these cells against autoimmune betacell destruction.

Acknowledgements. The authors thank J. Lyon for assistance with isolation of Sertoli cells, D. Dixon for assistance with islet transplantations and $\mathrm{A}$. Fu for assistance with immunohistochemical assays.

\section{References}

1. Barker CF, Billingham RE (1977) Immunologically privileged sites. Adv Immunol 25: 1-54

2. Selawry HP, Whittington K (1984) Extended allograft survival of islets grafted into the intra-abdominally placed testis. Diabetes 33: 405-406

3. Bellgrau D, Selawry H (1990) Cyclosporine-induced tolerance to intratesticular islet xenografts. Transplantation 50: 654-657

4. Griffith TS, Brunner T, Fletcher SM, Green DR, Ferguson TA (1995) Fas ligand-induced apoptosis as a mechanism of immune privilege. Science 270: 1189-1192

5. Streilein JW (1995) Unraveling immune privilege. Science 270: 1158-1159

6. French LE, Hahne M, Viard I et al. (1996) Fas and Fas ligand in embryos and adult mice: ligand expression in several immune-privileged tissues and coexpression in adult tissues characterized by apoptotic cell turnover. J Cell Biol 133: 335-343

7. Bellgrau D, Gold D, Selawry H, Moore J, Franzusoff A, Duke RC (1995) A role of CD95 ligand in preventing graft rejection. Nature 377: 630-632

8. Takeda Y, Gotoh M, Dono K et al. (1998) Protection of islet allografts transplanted together with Fas ligand expressing testicular allografts. Diabetologia 41: 315-321

9. Lau HT, Yu M, Fontana A, Stoeckert CJ Jr (1996) Prevention of islet allograft rejection with engineered myoblasts expressing FasL in mice. Science 273: 109-112

10. Allison J, Georgiou HM, Strasser A, Vaux DL (1997) Transgenic expression of CD95 ligand on islet $\beta$ cells induces a granulocytic infiltration but does not confer immune privilege upon islet allografts. Proc Natl Acad Sci USA 94: 3943-3947

11. Kang SM, Schneider DB, Lin Z et al. (1997) Fas ligand expression in islets of Langerhans does not confer immune privilege and instead targets them for rapid destruction. Nat Med 3: 738-743

12. Muruve DA, Nicolson AG, Manfro RC, Strom TB, Sukhatme VP, Liberman TA (1997) Adenovirus-mediated expression of Fas ligand induces hepatic apoptosis after systemic administration and apoptosis of ex vivo-infected pancreatic islet allografts and isografts. Hum Gene Ther 8: 955-963

13. Whitmore WF III, Karsh L, Gittes RF (1985) The role of germinal epithelium and spermatogenesis in the privileged survival of intratesticular grafts. J Urol 134: 782-786

14. Selawry HP, Whittington K, Forster H (1988) Prolonged intratesticular islet allograft survival in the absence of steroidogenesis. Horm Met Res 20: 562-564

15. Cameron D, Whittington K, Schultz RE, Selawry H (1990) Successful islet/abdominal testis transplantation does not require Leydig cells. Transplantation 50: 649-653

16. Selawry HP, Cameron DF (1993) Sertoli cell-enriched fractions in successful islet cell transplantation. Cell Transplant 2: $123-129$

17. Korbutt GS, Elliott JF, Rajotte RV (1997) Cotransplantation of allogeneic islets with allogeneic testicular cell aggre- gates allows long-term graft survival without systemic immunosuppression. Diabetes 46: 317-322

18. Gotoh M, Maki J, Kiyoizumi T, Satomi S, Monaco AP (1985) An improved method for isolation of mouse pancreatic islets. Transplantation 40: 437-438

19. Steinberger A, Thanki KJ, Siegal B (1974) FSH binding in rat testes during maturation and following hypophysectomy. Cellular localization of FSH receptors. In: Dufau ML, Means AR (eds) Hormone Binding and Target Cell Activation in the Testis. Plenum, New York, pp 177-192

20. Wang YM, Sullivan PM, Petrusz P, Yarbrough W, Joseph DR (1989) The androgen-binding protein gene is expressed in CD1 mouse testis. Mol Cell Endocrinol 63: 85-92

21. Alejandro R, Shienvold FL, Vaerewyck Hajek SA, Pierce M, Paul R, Mintz DH (1984) A ganglioside antigen on the rat pancreatic $\beta$ cell surface identified by monoclonal antibody R2D6. J Clin Invest 74: 25-38

22. Suarez-Pinzon W, Sorensen O, Bleackley RC, Elliott JF, Rajotte RV, Rabinovitch A (1999) $\beta$-cell destruction in NOD mice correlates with Fas (CD95) expression on $\beta$ cells and proinflammatory cytokine expression in islets. Diabetes 48: 21-28

23. Jaeger C, Brendel MD, Hering BJ, Eckhard M, Bretzel RG (1997) Progressive islet graft failure occurs significantly earlier in autoantibody-positive than in autoantibody-negative IDDM recipients of intrahepatic islet allografts. Diabetes 46: 1907-1910

24. Seino K, Iwabuchi K, Kayagaki N et al. (1998) Chemotactic activity of soluble Fas ligand against phagocytes. J Immunol 161: 4484-4488

25. Miwa K, Asano M, Horai R, Iwakura Y, Nagata S, Suda T (1998) Caspase 1-independent IL- $1 \beta$ release and inflammation induced by the apoptosis inducer Fas ligand. Nat Med 4: $1287-1292$

26. Ottonello L, Tortolina G, Amelotti M, Dallegri F (1999) Soluble Fas ligand is chemotactic for human neutrophilic polymorphonuclear leukocytes. J Immunol 162: 3601-3606

27. Hunt P, Eardley DD (1986) Suppressive effects of insulin and insulin-like growth factor I (IGF-I) on immune responses. J Immunol 136: 3994-3999

28. Wyatt CR, Law L, Magnuson JA, Griswold MD, Magnuson NS (1988) Suppression of lymphocyte proliferation by proteins secreted by cultured Sertoli cells. J Reprod Immunol 14: 27-40

29. Hedger MP, Qin J-X, Robertson DM, de Kretser DM (1990) Intragonadal regulation of immune system functions. Reprod Fertil Dev 2: 263-280

30. Selawry H, Kotb M, Herrod HG, Lu Z-N (1991) Production of a factor, or factors, suppressing IL-2 production and $\mathrm{T}$ cell proliferation by Sertoli cell-enriched preparations. Transplantation 52: 846-850

31. DeCesaris P, Filippini A, Cervelli C et al. (1992) Immunosuppressive molecules produced by Sertoli cells cultured in vitro: biological effects on lymphocytes. Biochem Biophys Res Commun 186: 1639-1646

32. Skinner MK (1991) Cell-cell interactions in the testis. Endocr Rev 12: 45-77

33. Turek PJ, Malkowicz SB, Tomaszewski JE, Wein AJ, Peehl D (1996) The role of the Sertoli cell in active immunosuppression in the human testis. Br J Urol 77: 891-895

34. Weiner HL (1997) Oral tolerance: immune mechanisms and treatment of autoimmune diseases. Immunol Today 18: $335-343$

35. Piccirillo CA, Chang Y, Prud'homme GJ (1998) TGF- $\beta 1$ somatic gene therapy prevents autoimmune disease in nonobese diabetic mice. J Immunol 161: 3950-3956 